ENTREPRENEURSHIP AND SUSTAINABILITY ISSUES

ISSN 2345-0282 (online) http://jssidoi.org/jesi/ 2019 Volume 7 Number 1 (September)

http://doi.org/10.9770/jesi.2019.7.1(26)

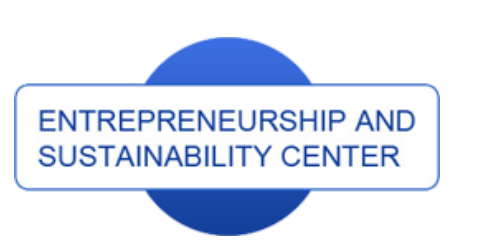

Publisher

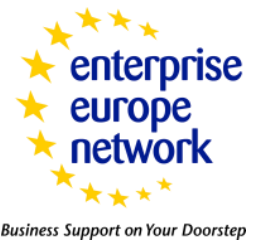

CASPA

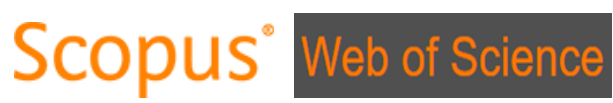

$\underline{\text { http://jssidoi.org/esc/home }}$

Business Support on Your Doorstep

I Clarivate

\title{
MODELLING THE CROWDFUNDING TECHNOLOGY ADOPTION AMONG NOVICE ENTREPRENEURS: AN EXTENDED TAM MODEL
}

\author{
Raouf Jaziri' ${ }^{1}$, Mohammad Miralam² \\ ${ }^{1,2}$ College of Business, University of Jeddah, \\ Asfan Road 285, P.O. Box: 42801, Jeddah 21551, Saudi Arabia \\ E-mails: ${ }^{1}$ rmjaziri@uj.edu.sa ; ${ }^{2 m m i r a l a m @ u j . e d u . s a ~}$
}

Received 25 February 2019; accepted 28 July 2019; published 30 September 2019

\begin{abstract}
Computer-mediated crowdfunding is deemed as an emerging technology used by novice entrepreneurs to solicit funds from other individuals in order to easily gather fundraising for their innovative ideas. However, lack of information on the attributes of crowdfunding platforms coupled with the lack of the knowledge about the techniques of use of these technologies make this fundraising tool not very effective. In this study, we try to elucidate, despite the unprecedented infatuation with the investment-based crowdfunding, key factors influencing the intention of Tunisian entrepreneurs to adopt crowdfunding platforms as a main tool of fundraising. The research model was based on an extended Technology Acceptance Model (TAM) with the integration of three new variables: perceived risk with service, perceived risk with transaction and plagiarism risk. The results shows that, both perceived risk with service, perceived risk with transaction and plagiarism risk have a negative impact on entrepreneurs' use of crowdfunding platforms, while perceived usefulness and perceived trust influence positively entrepreneurs' intention behavior. Perceived risks with crowdfunding service and transaction are affected by financing risk, security concerns and psychological factors, while plagiarism risk is influenced by information concerns, perceived control.
\end{abstract}

Keywords: crowdfunding; risk, trust; Technology Acceptance Model (TAM)

Reference to this paper should be made as follows: Jaziri, R.; Miralam, M. 2019. Modelling the crowdfunding technology adoption among novice entrepreneurs: an extended TAM model, Entrepreneurship and Sustainability Issues 7(1): 353-374. http://doi.org/10.9770/jesi.2019.7.1(26)

JEL Classifications: D81, L26, O33

Additional disciplines: information and communication

\section{Introduction}

It is broadly recognized that crowdfunding has radically metamorphosed the entrepreneurial finance ecosystem. It is defined as an open call over an Internet platform for financial resources in the form of a monetary donation, an exchange for a future product, service, or reward (Kleemann et al., 2008; Belleflamme et al., 2011; Astrauskaite, Paškevičius, 2018). Commonly, crowdfunding uses web technologies and especially e-payment platforms to 


\section{ENTREPRENEURSHIP AND SUSTAINABILITY ISSUES}

ISSN 2345-0282 (online) http://jssidoi.org/jesi/

2019 Volume 7 Number 1 (September)

http://doi.org/10.9770/jesi.2019.7.1(26)

facilitate electronic transactions between entrepreneurs requesting funds and crowdfunders giving funds. Crowdfunding platforms, such as Ulule, Indiegogo and Kickstarter, give the opportunities, to raise funding, for young entrepreneurs by pitching an innovative idea to their social network.

Asking money from the crowd still in contradiction with classical fundraising ways such as securing funding from banks, venture capitalists and business angels. In fact, Novice Entrepreneurs create their profiles on a crowdfunding platform and clarify their monetary objectives, planning of funds' use, and schedule for objectives attainment.

Nowadays, there is an exponential growth in the number of crowdfunding websites. According to the study reported by the University of Cambridge and KPMG (2016), 5.431 billion euros were exchanged in 2015 in Europe on specialized platforms including 4,412 billion in the United Kingdom alone (Cambridge/KPMG, 2016). As a result, all European countries have a regulatory framework dedicated to crowdfunding phenomenon. However, the United States and Asia are major players in crowdfunding. Investments were worth 33.6 billion euros and 94.6 billion euros respectively in 2015. Indeed, Terry et al. (2015: 8) consider crowdfunding as "potentially the most disruptive of all the new models of finance," with the World Bank (2015) predicting that crowdfunding investments will be a $\$ 96$ billion a year market in developing countries alone by 2025 .

In the other side of the world, Africa still the lowest performing crowdfunding markets (Chirisa \& Mukarwi, 2018). In Africa, crowdfunding is a challenge hindered by the lack of legal texts supporting it. Within this framework, crowdfunding is deemed as a new opportunity that can enable funding transfer from donators or investors to entrepreneurs looking for raise funding (Pazowski \& Czudec, 2014).

This study is expected to be of substantial interest to both researchers and entrepreneurs. From the academic side, this paper not only makes contributions to research on crowdfunding, however, practically, the results suggest new insight for crowdfunding technology adoption by novice entrepreneurs in order to promote the development of crowdfunding.

\section{Literature Review}

Crowdfunding owes its origin to the concept of crowdsourcing that means the outsourcing of problem-solving tasks to a distributed network of individuals (Howe, 2006). Crowdfunding makes it possible for those with limited access to traditional sources of financial backing, such as banks or venture capitalists, to acquire financial resources necessary to pursue their projects. Through online transactions, crowdfunding also gives people with disposable income a new way to give to others and "invest" in projects that might not happen without their financial support

Crowdfunding has arisen as an unconventional source of raise funding for different types of entrepreneurial projects and as one of the most interesting tool of Internet finance (Li et al., 2016). In fact, within a crowdfunding campaign, the novice entrepreneurs describe their entrepreneurial projects, choose the appropriate funding instrument and fixe a funding objective and the financial contribution of each funder, as well as the reward of each one of them (Mollick, 2014).

There are four different types of crowdfunding: rewards-based crowdfunding, donation-based crowdfunding, Equity crowdfunding, and lending crowdfunding (Ahlers et al., 2015). In rewards-based crowdfunding platforms such as Kickstarter and Indiegogo, crowdfunders pay small amounts of money in exchange for a reward, which is often the produced item. In donation-based crowdfunding, crowdfunders donate deliberately small amounts without any reward. Usually donation-based crowdfunding platforms are used to raise money for a non-profit or a cause. However, lending platforms and equity platforms are distinguished. In the first case, crowdfunders lend 


\section{ENTREPRENEURSHIP AND SUSTAINABILITY ISSUES}

ISSN 2345-0282 (online) http://jssidoi.org/jesi/

2019 Volume 7 Number 1 (September)

http://doi.org/10.9770/jesi.2019.7.1(26)

money to entrepreneurs and make profits with interest. In the second case, investors take shares in the new startup seeking raise funding.

Crowdfunding has widely stimulated the interest of researchers in business management. In fact, there are various publications dealing with themes such as crowdfunders' motivations for crowdfunding (Bretschneider et al., 2014) and identifying key factors for a raise funding campaign (Belleflamme et al., 2013). Conversely, there is no studies have been conducted on the factors influencing the acceptance of using crowdfunding platforms neither by entrepreneurs nor by fundraisers in developing countries which are deprived of this technology. For example, Lei et al. (2018) found that potential funders' decision-making process is influenced by different types of uncertainty and risks associated to entrepreneurs' project. In fact, in traditional e-commerce consumers buy a finished product, inversely for funders via crowdfunding platforms, they buy a product that is not yet to be finished. This generates an uncertainty based on perceived trust, perceived risk and perceived usefulness among both novice entrepreneurs who are worry about their project disclosure and funders who are worry about their funds being misappropriated or diverted. While Risk perception theory (RPT) provides a consistent view of subjective risk, we think that adjustments are necessary because researchers have argued that the explanatory power of a theory have to be contingent on the technology's features (Featherman \& Pavlou, 2003). In this paper, we take into account the plagiarism risk as mediating variables in addition to risk with services and risk with transaction.

Other studies have also confirmed that information disclosure on the crowdfunding platforms reduces information asymmetry (Mollick, 2014) and increases also the probability of raise funding accomplishment (Ahlers et al., 2015). Nevertheless, there is no previous empirical studies has been performed to identify factors of the intention to use voluntary crowdfunding platforms by novice entrepreneurs in developing countries where crowdfunding platforms are still absent. The aim of our current study was to investigate factors influencing the acceptance of using crowdfunding platforms among Tunisian entrepreneurs. We lead a study among 100 novice entrepreneurs hosted in 12 different business incubators.

\section{Theoretical framework and hypotheses}

Many researchers have proposed several models of technology acceptance in order to predict users' intention of a specific technology. The measurement of both user experience and satisfaction of several new technological tools have a very interesting importance, especially at the recent shutdown of Google Glass project (Shin \& Hwang, 2017). This essential defy stimulated different researchers to propose many acceptance models of technology by potential users. In fact, Fishbein \& Ajzen (1977) and Davis (1989) have proposed and verified their theories, and models of the intention to use of technologies. Explicitly, our theoretical framework should referred to the following models and theories:

- Technology Acceptance Model - TAM (Davis, Bagozzi, Warshaw, 1989),

- Theory of Planned Behavior -TPB (Fishbein \& Ajzen, 1977),

- Innovation Diffusion Theory - IDT (Moore and Benbasat 1991),

- Motivational Model (Davis, Bagozzi, and Warshaw 1992),

- Combined Model of TAM and TPB (Taylor \& Todd, 1995),

- Social Cognitive Theory (Compeau \& Higgins, 1995),

- TAM 2 (Venkatesh \& Davis, 2000),

- Unified Theory of Acceptance and Use of Technology or UTAUT (Venkatesh et al. 2003),

- TAM 3 (Venkatesh \& Bala, 2008).

In this context, many authors carried out various studies dealing deeply with comparative analysis of theories and models of technology acceptance (Venkatesh et al., 2003; Roca \& Gagné, 2008; Shin \& Biocca, 2017; Jaziri \& Touhami, 2018). Moreover, TAMs, have particular attention in the research area of technology adoption. TAM allows us to predict behavioral intention as dependent variables. As our research aims to explore the determinants 
of crowdfunding technology adoption by Tunisian novice entrepreneurs, we think that TAM associated with theories of perceived risk and trust could estimate the behavioural intention to use crowdfunding platforms. In fact, Researches overseas confirm that perceived risk and trust are two crucial variables of crowdfunding adoption. Furthermore, as crowdfunding is a new technology not applied yet in Tunisia, TAM can be considered as suitable to study the acceptance of using crowdfunding platforms by entrepreneurs.

With the widespread of web 2.0 technology, many researchers have applied and adjusted the TAM to this environment. Bomil \& Han (2002:248) highlighted that perceived usefulness and perceived ease of use are not sufficient to predict the intention to use technology. In fact, security and privacy are two other important considerations for a user (Luarn \& Lin., 2005). Therefore, we adopt three mediating variables related to risk especially: perceived risk with crowdfunding service, perceived risk with online crowdfunding transaction (Lee et al., 2001) and Plagiarism Risk. On the other hand, we adopt one mediating variable related to "perceived trust" (Malhotra et al., 2004).

In order to predict the willingness to use crowdfunding platforms (UCP) by Tunisian novice entrepreneurs, we use simultaneously perceived usefulness and both Perceived Risk and Perceived Trust theories as theoretical basis. All these mediating variables can be illustrated in the proposed research model in Figure 1.

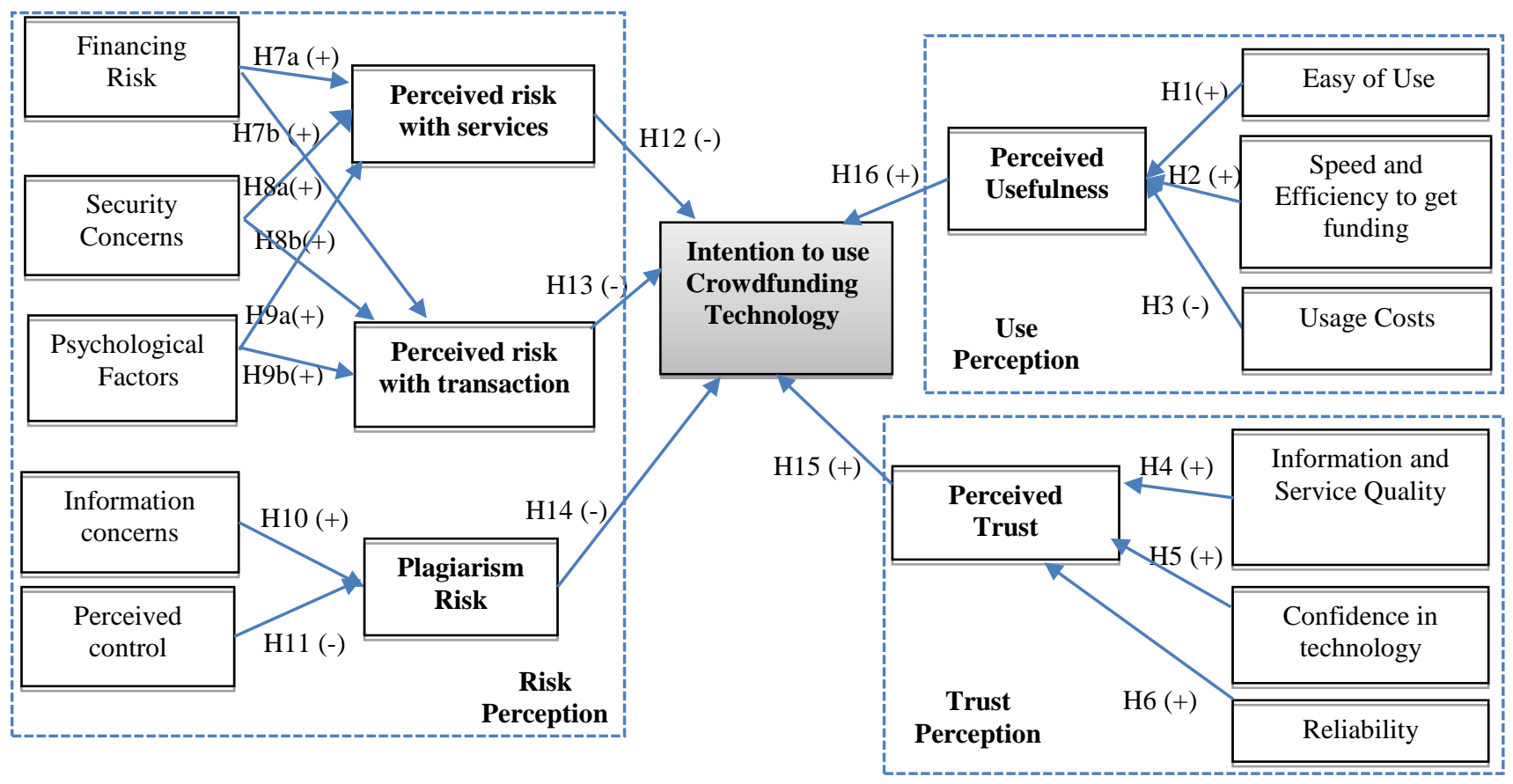

Figure 1. Research model Source: authors

\subsection{Mediating variables}




\section{ENTREPRENEURSHIP AND SUSTAINABILITY ISSUES}

ISSN 2345-0282 (online) http://jssidoi.org/jesi/

2019 Volume 7 Number 1 (September)

http://doi.org/10.9770/jesi.2019.7.1(26)

Usage of crowdfunding technology is the final dependent variable. Three key principles drive the usage of these platforms i.e. how useful it is for novice entrepreneur to use this technology, how much risk is involved in terms of security concerns and given the risk involved can trust still be built upon for entrepreneurs to use crowdfunding platforms.

\section{Perceived Usefulness (PU)}

Davis (1993) defined Perceived Usefulness as "the degree to which an individual believes that using a particular system would enhance his or her job performance". Moreover, he defined the attitude toward use of a technology as "the degree to which an individual evaluates and associates the target system with his or her job" (p. 476). Accordingly, this study proposes the following hypothesis:

H16: Crowdfunding platform will get a positive impetus if perceived useful

Davis (1989) recognises two different constructs, Perceived Ease of Use (EU) and Perceived Usefulness (PU). These two latent constructs affect directly the attitude of an individual toward the target technology use and affect indirectly the use of actual system use (Davis, 1993: 477).

Perceived Ease of Use as "the degree to which an individual believes that using a particular system would be free of physical and mental effort". Adams et al. (1992) replicated the research of Davis (1989) to validate these scales that are determined by four beliefs: easy to learn, controllable, easy to become skilful and clear and understandable. Accordingly, this study proposes the following hypothesis:

$\mathrm{H} 1$ : Ease of use (EU) has positive impact on the intention to use crowdfunding platforms

Referring to the five dimensions of Perceived usefulness proposed by Adams et al. (1992), we recognized as usefulness categories related to crowdfunding service: get funding more quickly, job performance, increase productivity, effectiveness and make fund raising easier. Crowdfunding platforms allows novice entrepreneurs to have direct access to funders and avoid bureaucratic procedures of ordinary financial institutions. Crowdfunding technology increases entrepreneur's chances to get funding especially those who have not access to traditional funding institutions (Banks, Venture Capital, etc.). In addition, crowdfunding platforms could increase the project productivity in case the collected funds exceed the requested amount. In a crowdfunding campaign, the novice entrepreneur is required to introduce his idea and convince the investors to be engaged effectively in his project. The entrepreneur is in direct relation with crowdfunders and he is more implicated and more efficient in his fundraising. Procedures of a crowdfunding campaign are easier and simpler compared to those of obtaining credit from other funding institutions.

Speed and Efficiency (SE) of crowdfunding platforms as it uplifts the performance of getting funding quickly is positively impacts adoption of this technology. The efficiency of crowdfunding systems would involve handling sophisticated platforms, thereby adding value to the entrepreneurs. Therefore, this paper proposes the following hypothesis:

H2: Speed and Efficiency to get funding has a positive influences perceived usefulness in crowdfunding.

The voluntary information disclosure by the entrepreneur increases the confidence of crowdfunders, helps public investors to make better capital allocation decisions, and lowers firms' capital costs (Wang et al., 2015).

Therefore, this paper proposes the following hypothesis:

H3: Usage costs (UC) is associated negatively with the perceived usefulness of crowdfunding platforms.

\section{Perceived trust (PT)}




\section{ENTREPRENEURSHIP AND SUSTAINABILITY ISSUES}

ISSN 2345-0282 (online) http://jssidoi.org/jesi/

2019 Volume 7 Number 1 (September)

http://doi.org/10.9770/jesi.2019.7.1(26)

Zheng et al., (2016) defined trust as a sentiment of security and the disposition to depend on someone or something. Trust is considered as a dynamic process and is built over a certain period of time contributing to satisfaction beyond the effects of the economic outcome (Fam et al., 2004, p. 198). Chen (2006) argued that perceived trust has two means. The first it is a belief, attitude, confidence, or an expectation about honesty of another party's (the funders' trustworthiness in our case). The second consider trust as a behavioral intention including uncertainty. Therefore, this paper proposes the following hypothesis:

H15: Perceived trust (PT) has positive impact on the intention to adopt crowdfunding.

Furthermore, there are three basic dimensions of perceived trust namely: Information and service quality (ISQ), confidence in technology (CT) and reliability (REL) (Kim et al., 2011). According to Zheng et al., (2000) trust is achieved by regular use of reward-based crowdfunding technology. Accordingly, this study proposes the following hypothesis:

H4: Information and service quality has positive effect on perceived trust.

H5: Confidence in technology has positive impact on perceived trust.

H6: Reliability is positively related to perceived trust.

\section{Perceived risk with service (PRS)}

Bauer (1960) was the first to introduce the concept of "perceived risk" to marketing literature. Since 1960, extensive researches haves shown that perceived risk affects the behaviour across different cultures. The theory of perceived risk explains that people perceive risk because they face uncertainty and potentially undesirable consequences, so they expect some kind of loss.

Therefore the more risk they perceive the less likely they will intend to try the service. Gierczak et al., (2014) argues that dependence on sources of information reduce crowdfunders' perceived risk with the crowdfunding service adoption. Wang et al., (2018), show from a risk-perception view the concerns of fundraisers' voluntary information disclosure on crowdfunding platforms.

Fundraisers make decisions regarding crowdfunding services to buy. The results of fundraising are often uncertain and the entrepreneur perceives the risk in making a purchase decision. The degree of risk that fundraisers perceive and their own tolerance for risk taking are factors that influence their adoption of crowdfunding platforms. Therefore, this paper proposes the following hypothesis:

H13: Perceived risk with crowdfunding services (PRS) is associated negatively with the intention to use crowdfunding platforms.

Among the five risk categories proposed by Jacoby \& Kaplan (1974) and confirmed by Park et al. (2004), we recognized as risk types related to crowdfunding service: functional loss, time loss, financial loss and opportunity loss. Crowdfunding platforms could not function as expected because of technical problems or wrong manipulation. In the rewards-based crowdfunding campaigns such as "All-or-Nothing" (AON), entrepreneurs risk wasting time in case they do not reach the target amount before the deadline of the campaign. As crowdfunding websites are relatively new phenomenon, there is still no guarantee regarding the credibility and the seriousness of the platform transactions. With professional investors such as business angels and venture capitalists, ideas are disclosed in a relatively small circle of investors, each of whom may incur reputational costs from stealing ideas. In contrast, in a crowdfunding campaign entrepreneurs should disclose their entrepreneurial idea in the internet before the product is actually produced making ideas tealing and replicability more likely. This practice stands in sharp contrast with concerns of many entrepreneurs who pursue that innovative ideas need to remain undisclosed. Fundraisers' perceptions of financing risk rise. Accordingly, the following hypotheses are proposed:

H7a: Perceived monetary concerns especially financing risk (FR) is positively related to perceived risk with crowdfunding services.

H8a: Security concerns (SC) is associated positively with perceived risk with crowdfunding services. 


\section{ENTREPRENEURSHIP AND SUSTAINABILITY ISSUES}

ISSN 2345-0282 (online) http://jssidoi.org/jesi/

2019 Volume 7 Number 1 (September)

http://doi.org/10.9770/jesi.2019.7.1(26)

H9a: psychological factors (PF) has positive effect on perceived risk with crowdfunding services.

\section{Perceived risk with transaction (PRT)}

Several studies have suggested the lack of security and privacy over an electronic transaction as a frequently recognized obstacle to the use of information and communication technology (Rose et al. 1999; Swaminathan et al. 1999; Lee et al., 2000). Novice entrepreneurs are proposing a plan built around "micro-investors" that they think would minimize the risk of "fraudfunding" (Hazen, 2012). However, fundraising is conditioned by the entrepreneur's disclosure of his project idea to investors. Entrepreneurs face transaction risks such as the lack of security, stealing his idea and privacy concerns. Therefore, this paper proposes the following hypothesis:

H12: Perceived risk with transaction (PRT) via crowdfunding platform is negatively related to the intention of use of this technology.

Perceived risk with transaction is determined by the following dimensions: Privacy, security and non-repudiation. Rose et al. (1999) noted that privacy is vulnerable because messages on the Internet are being passed in a shared domain, and consumers are not yet comfortable with sending personal information across Internet. Moreover, Swaminathan et al. (1999) argued that security concerns with respect to exposure personal information to hackers or unknown individuals, is still a major anxiety for consumers. The possibility that a part can deny an agreement after the transaction represents a risk for entrepreneurs. Accordingly, the following hypotheses are proposed:

H7b: Perceived monetary concerns especially financing risk (FR) is positively related to perceived risk with transaction via crowdfunding platform.

H8b: Security concerns (SC) is associated positively with perceived risk with transaction via crowdfunding platform.

H9b: psychological factors (PF) has positive effect on perceived risk with transaction via crowdfunding platform.

\section{Plagiarism Risk (PR)}

The construct of Plagiarism risk (PR) is a belief that negatively impacts entrepreneur idea disclosure (Dinev et al., 2006). In our study, plagiarism risk is considered as an obstacle to information disclosure about the entrepreneurial project, which can lead to project abortionand loss of comparative advantages (Bulgurcu et al., 2010; Xu et al., 2013). In a crowdfunding campaigns, information related to the originality of the entrepreneurial project are critical and are very important for fundraisers. The loss of principal information could hinder the project's concretization of fundraisers ( $\mathrm{Li}$ et al., 2016). When entrepreneurs divulge information about their entrepreneurial project on crowdfunding platforms, they incur the plagiarism risk or the illegal imitation of their original information by unscrupulous users. In this case, novice entrepreneurs will vacillate to disclose information related to their entrepreneurial projects on the crowdfunding platforms. Therefore, this paper proposes the following hypothesis:

H14: Plagiarism risk (PR) is negatively related to the intention of use of crowdfunding platforms.

Information concerns (IC) are considered as an interesting construct in preceding research on information revelation via social media (Xu et al., 2013). In crowdfunding context, it involves fundraisers' concern about threats to disclose their project's information online and incur the risk of information leakage (Dinev et al., 2006). Bulgurcu et al., (2010) argue that social media users are becoming more and more concerned with the security of their personal information revelation. As a result, as entrepreneurs' information worries rise, their perceptions of plagiarism risk increase. Therefore, we propose the following hypothesis:

H10: Information concerns (IC) have a positive impact on plagiarism risk (PR).

Perceived control (PCL) is another construct representing how much control entrepreneur have over who can perceive their information (Zlatolas et al., 2015). In their empirical study Xu et al., (2008) have shown a negative relationship between Perceived control and information risk. Analogically if fundraisers have more control of their Project's information they divulge, they perceive less risk (Krasnova et al., 2010). Consequently, entrepreneurs want to control who can evaluate their personal information. In fact, as entrepreneurs' control over 


\section{ENTREPRENEURSHIP AND SUSTAINABILITY ISSUES}

ISSN 2345-0282 (online) http://jssidoi.org/jesi/ 2019 Volume 7 Number 1 (September) http://doi.org/10.9770/jesi.2019.7.1(26)

disclosed information grow their plagiarism risk perception decrease (Xu et al., 2008). Accordingly, this paper proposes the following hypothesis:

H11: Perceived control (PCL) is negatively associated with plagiarism risk (PR).

\section{Research methodology}

\subsection{Measurement development}

For the operationalization of constructs, we chose to adapt existing validated measurement items identified from the reviewed literature (see Table I), introducing only slight changes to make them pertinent in the context of crowdfunding. The measurement items were formulated as a five point Likert scale, ranging from 1 'strongly agree' to 5 'strongly disagree'. As the measurement items were initially generated in English, we translate the questionnaire in French and Arabic language by adapting standard procedure of translation. Five colleagues in entrepreneurship and entrepreneurial finance who are familiar with survey conception and crowdfunding issues have evaluated the questionnaire. Furthermore, the questionnaire was pre-test by $10 \mathrm{PhD}$ students in entrepreneurship through snowball sampling. The questionnaire testers were asked to comment any vague items, which are subsequently refined. As web based surveys are appropriate when the target are internet users and a short time of responses is required, the participants were first contacted via e-mail and provided an online web link to the questionnaire (Lee et al., 2001). Firstly, the questionnaire was sent by mail to 288 entrepreneurs incubated and hosted in 24 Tunisian business incubators, but the response rate was so low (2.3\%). Four weeks later, the questionnaire was sent again to entrepreneurs that did not initially respond which improve the response rate to $10.8 \%$. Thirdly, we boost the response rate to $27.98 \%$ by using phone calls. Finally, since an empirical evidence shows that incentives boost participation in the online survey (Li et al., 2006; Zlatolas et al., 2015) we decide to offer pre-paid mobile phone cards as gifts for respondents. Consequently, the final rate of response to the questionnaire was $72.22 \%$ (208 of 288 entrepreneurs). According to Hair et al. (2006), using structural equation modeling (SEM) requires a sample size between 200 and 400 to obtain precise results. In addition, Kline (2016) argued that the sample size for SEM should be larger than 200.

The collected test data were used for the exploratory factor analysis (EFA) and reliability analysis with SPSS 25.0. The result of data analysis indicated that the stability coefficients and Cronbach's alphas exceeded 0.7 for the remaining 37 measurement items (Table 1).

Table 1. Measurement items

\begin{tabular}{|c|c|c|c|}
\hline Construct & Code & Items & References \\
\hline $\begin{array}{l}\text { Information } \\
\text { concern }\end{array}$ & $\mathrm{IC}$ & $\begin{array}{l}\text { I am concerned that unauthorized people may access my project's information. } \\
\text { I am concerned that the crowdfunding platform is collecting too much of my } \\
\text { project's information. } \\
\text { I am concerned that the crowdfunding platform may share my project's } \\
\text { information in an inaccurate manner. }\end{array}$ & Xu et al. (2013) \\
\hline $\begin{array}{l}\text { Perceived } \\
\text { control }\end{array}$ & PCL & $\begin{array}{l}\text { I believe that I have control over how the crowdfunding platform uses my project's } \\
\text { information. } \\
\text { I believe that I have control over who can access my project's information } \\
\text { that I post on the crowdfunding platform. } \\
\text { I believe that I have control over the project information that is visible to others on } \\
\text { the crowdfunding platform. }\end{array}$ & $\begin{array}{l}\mathrm{Xu} \text { et al. } \\
(2008)\end{array}$ \\
\hline Plagiarism risk & PR & $\begin{array}{l}\text { I perceive a real threat to my project, such as plagiarism and abuse on the } \\
\text { crowdfunding platform. } \\
\text { I fear that my project will be illegally copied by individuals or organizations } \\
\text { without my consent. } \\
\text { Overall, I'm afraid that there will be intellectual property disputes in the future } \\
\text { operation of my project. }\end{array}$ & $\begin{array}{l}\text { Malhotra et al. } \\
\text { (2004) }\end{array}$ \\
\hline $\begin{array}{l}\text { Perceived Risk } \\
\text { with services }\end{array}$ & PRS & I would find crowdfunding platforms services risky & $\begin{array}{l}\text { Lee et al., } \\
(2001)\end{array}$ \\
\hline Perceived Risk & PRT & I would find crowdfunding platforms' transactions risky & Lee et al., \\
\hline
\end{tabular}




\section{ENTREPRENEURSHIP AND SUSTAINABILITY ISSUES}

ISSN 2345-0282 (online) http://jssidoi.org/jesi/ 2019 Volume 7 Number 1 (September) http://doi.org/10.9770/jesi.2019.7.1(26)

with transaction

Financing risk

Security

Concerns

Psychological

factors

Perceived

usefulness

Ease of use

Speed and

efficiency

Usage cost

Perceived trust

PT

Information and service quality

confidence in crowdfunding technology

Reliability

Intention to use

FR

SC

PF

PU

(1)
Using a crowdfunding platform would enable me to get funding more quickly
Using a crowdfunding platform would improve my chances to get funding

Using a crowdfunding platform would increase the productivity of my project in case the funds collected exceed the requested amount

Using a crowdfunding platform would enhance my effectiveness on getting funding

Using a crowdfunding platform would make it easier for me to get funding

EU It would be easy for me to learn how to use a crowdfunding platform

I would find it easy to get a crowdfunding platform to do what I want it to do

It would be easy for me to remember how to use a crowdfunding platform

My interaction with a crowdfunding platform would be clear and understandable

SE I do not find Crowdfunding technology time consuming

With crowdfunding platform, I am on- the-go and can have funds with the touch of a button

UC I am not reluctant to use crowdfunding platform because I can not support any charge in case of failure of the campaign

I am not reluctant to use crowdfunding platform because Crowdfunding platform's owner charges me for using it

Crowdfunding platforms have integrity

Crowdfunding platforms are reliable

Crowdfunding platforms are trustworthy

ISQ Crowdfunding does not annoy me even if I have to remember different passwords or codes

It would be easy to surf and access different services in crowdfunding platforms

In crowdfunding platforms "how to use guides" are provided on the website

CT I prefer launching a crowdfunding campaign rather than raising funds directly from my acquaintances

I trust the current generation of online services including crowdfunding platforms

REL Using crowdfunding technology enhance correct transaction records

Using crowdfunding technology enhance zero-error in services

$\mathrm{UC}$

(2001)

Featherman \&

Pavlou (2003)

Lee et al.,

(2001)

Taherdoost

(2017)

Taherdoost \&

Sahibuddin

(2015)

Tan \& Teo,

(2000)

Davis (2003)

Suh \& Han

(2003)

Taherdoost

(2018)

Malhotra et al., 2004

Malhotra et al., 2004

Malhotra et al., 2004

Malhotra et al., 2004

$\mathrm{Wu}$, Tao, and

Yang (2008)

Venkatesh et al.

I predict I would use crowdfunding platforms in the near future

I plan to use crowdfunding platforms in the near future

(2003),

My intention would be to use crowdfunding platforms rather than traditional financing tools

Information about the respondents' demographics are listed in Table 2. The demographic characteristics of our sample shows different demographic factors, including gender, age, business activity, diploma and education background. 
Table 2. Sample demographics $(n=208)$.

\begin{tabular}{llll}
\hline \multirow{2}{*}{ Measures } & Items & Frequency & Percentage \% \\
\hline Gender & Male & 132 & 63.46 \\
Age & Female & 76 & 36.54 \\
& Under 30 & 134 & 64.42 \\
Educational level & $30-40$ & 56 & 26.92 \\
& 40 or above & 18 & 8.66 \\
& Bachelor & 113 & 54.33 \\
Educational background & Master & 21 & 10,1 \\
& Engineering & 69 & 33.17 \\
& PhD & 5 & 2.4 \\
& Human sciences & 12 & 5.76 \\
& Computer sciences & 141 & 67.78 \\
Business activity & Medical sciences & 4 & 1.92 \\
& Business \& Economics & 46 & 22.11 \\
& Tourism Management & 5 & 2.40 \\
& Services & 79 & 37.98 \\
& Industry & 125 & 60,09 \\
\hline
\end{tabular}

\section{The results}

This study outlines a research model with five latent constructs, each of them was measured by three or more variables. Data analysis was carried out using SEM as a flexible tool in scrutinising causal relationships between multiple-item constructs (Kline, 2016). The benefits of SEM analysis consist of assumptions that are more flexible and fewer measurement errors permitted by several indicators per construct (Kline, 2016). Before testing our research model, we performed manipulation to validate the treatment. We use a two-step process to specify a measurement model in the confirmatory factor analysis (CFA), then we test our latent structural model established from the measurement model (Anderson and Gerbing, 1988).

Measurement model validation

The 208 responses used for data analysis indicate a satisfactory sample size about $72.22 \%$. We use confirmatory factor analysis (CFA) to assess our measurement model and to ensure validity and reliability (Brown, 2015). Overall goodness-of-fit indices for the initial measurement model showed that the fit was acceptable, with the chisquare/df ratio $(\chi 2 /$ d.f.) of 1.76 , root-mean-squared error of approximation (RMSEA $=0.05)$, comparative fit index $(\mathrm{CFI}=0.93)$, goodness of fit index $(\mathrm{GFI}=0.92)$, adjusted goodness of fit index (AGFI=0.92), normed fit index $(\mathrm{NFI}=0.94)$, Bollen's incremental-fit index $(\mathrm{IFI}=0.95)$, comparative fit index $(\mathrm{CFI}=0.95)$ all having acceptable fit levels.

To evaluate the reliability of the constructs we calculate Cronbach's $\alpha$ and in order to measure internal consistency we determine composite reliability (CR) (Fornell \& Larcker, 1981). In fact, for a construct to have good reliability, Cronbach's $\alpha$ should be superior to 0.7 , while internal consistency (CR) should be at least 0.7 (Hair et al., 1998). The Table 3 indicates a good reliability and shows that all values exceeded generally accepted values. Construct validity includes convergent validity and discriminant validity. Convergent validity measures whether items effectively reflect their corresponding factors (Brown, 2015).

Table 3. Standardized item loadings, AVE, CR and Cronbach's $\alpha$ values. 


\begin{tabular}{|c|c|c|c|c|c|}
\hline Constructs & Items & $\begin{array}{l}\text { Standardized } \\
\text { item loading }\end{array}$ & $\mathbf{C R}$ & AVE & Cronbach's $\alpha$ \\
\hline \multirow[t]{5}{*}{ Perceived usefulness } & $P U 4$ & 0.858 & 0.8742 & 0.7341 & 0.850 \\
\hline & PU2 & 0.846 & & & \\
\hline & PU5 & 0.838 & & & \\
\hline & PU1 & 0.836 & & & \\
\hline & PU3 & 0.822 & & & \\
\hline \multirow[t]{3}{*}{ Perceived trust } & $P T 1$ & 0.932 & 0.9565 & 0.8871 & 0.946 \\
\hline & PT3 & 0.928 & & & \\
\hline & $P T 2$ & 0.907 & & & \\
\hline \multirow[t]{3}{*}{ Plagiarism risk } & $P R 2$ & 0.836 & 0.8432 & 0.6564 & 0.824 \\
\hline & $P R 3$ & 0.834 & & & \\
\hline & PRl & 0.828 & & & \\
\hline \multirow[t]{3}{*}{ Financing risk } & $F R 2$ & 0.886 & 0.8675 & 0.7332 & 0.843 \\
\hline & FR3 & 0.866 & & & \\
\hline & FRl & 0.843 & & & \\
\hline \multirow[t]{2}{*}{ Psychological factors } & $P F 2$ & 0.941 & 0.94229 & 0.8339 & 0.944 \\
\hline & $P F 1$ & 0.886 & & & \\
\hline \multirow[t]{4}{*}{ Security concerns } & $S C 1$ & 0.849 & 0.8291 & 0.8124 & 0.921 \\
\hline & $S C 2$ & 0.831 & & & \\
\hline & $S C 3$ & 0.829 & & & \\
\hline & $S C 4$ & 0.812 & & & \\
\hline \multirow[t]{3}{*}{ Information concerns } & $I C 2$ & 0.879 & 0.9246 & 0.7967 & 0.881 \\
\hline & ICI & 0.866 & & & \\
\hline & IC3 & 0.857 & & & \\
\hline \multirow[t]{3}{*}{ Percived control } & $P C 3$ & 0.885 & 0.9132 & 0.7614 & 0.842 \\
\hline & $P C 1$ & 0.862 & & & \\
\hline & $P C 2$ & 0.854 & & & \\
\hline \multirow[t]{2}{*}{ Speed and efficiency } & $S E 1$ & 0.887 & 0.9321 & 0.7753 & 0.832 \\
\hline & $S E 2$ & 0.874 & & & \\
\hline \multirow[t]{2}{*}{ Usage costs } & $U C 1$ & 0.867 & 0.9426 & 0.7821 & 0.863 \\
\hline & $U C 2$ & 0.843 & & & \\
\hline \multirow[t]{2}{*}{ Reliability } & REL1 & 0.891 & 0.9365 & 07859 & 0.857 \\
\hline & $R E L 2$ & 0873 & & & \\
\hline \multirow[t]{4}{*}{ Easy of use } & EU1 & 0.876 & 0.9115 & 0.7525 & 0.832 \\
\hline & $E U 3$ & 0.871 & & & \\
\hline & EU4 & 0.866 & & & \\
\hline & $E U 2$ & 0.852 & & & \\
\hline \multirow[t]{3}{*}{ Information \& service quality } & $I S Q 1$ & 0.892 & 0.9203 & 0.7731 & 0.844 \\
\hline & $I S Q 2$ & 0.879 & & & \\
\hline & $I S Q 3$ & 0.874 & & & \\
\hline
\end{tabular}


ENTREPRENEURSHIP AND SUSTAINABILITY ISSUES

ISSN 2345-0282 (online) http://jssidoi.org/jesi/ 2019 Volume 7 Number 1 (September) http://doi.org/10.9770/jesi.2019.7.1(26)

$\begin{array}{llllll}\text { Confidence in technology } & C T 1 & 0.873 & 0.9119 & 0.7648 & 0.832 \\ & C T 2 & 0.857 & & & \\ \text { Intention to use } & I U 1 & 0.966 & 0.9674 & 0.8984 & 0.958 \\ & I U 2 & 0.957 & & & \\ & I U 3 & 0.931 & & & \\ & I U 4 & 0.912 & & & \end{array}$

In this study we use average variance extracted (AVE) to assess the convergent and discriminant validity of the constructs' measurement. To confirm convergent validity, the factor loading of every item should be superior to 0.7, and each construct should have the CR value larger than 0.7, and the AVE value greater than 0.5 (Fornell \& Larcker 1981). As presented in Table 3, all factor loadings for the items are greater than 0.7 and were significant at the 0.001 level, all AVEs are superior than 0.5 and the CRs exceeded 0.7. Consequently, the scale showed good convergent validity. Therefore, to measure if two factors are significantly different we use discriminant validity (Kline, 2016).

Discriminant validity is shown when:

1. measurement items load more strongly on their assigned construct rather than on the other constructs in the CFA, and

2. the square root of the Average Variance Extracted (AVE) of each construct is greater than its correlations with the other constructs (Hair et al., 1998).

3. As shown in Table 4, the square root of the AVE for each construct is greater than the correlation shared among constructs in the research model, thus providing evidence of discriminant validity.

Table 4. The square roots of AVEs and factor correlation coefficients.

\begin{tabular}{|c|c|c|c|c|c|c|c|c|c|c|c|c|c|c|c|c|c|}
\hline Constr.ı & $1 \mathrm{PU}$ & $\mathrm{EU}$ & SE & $\mathrm{UC}$ & PT & ISQ & $\mathrm{CT}$ & REL & PRS & PRT & FR & $\mathrm{SC}$ & $\mathrm{PF}$ & PR & IC & $\mathrm{PC}$ & UCT \\
\hline PU & .843 & & & & & & & & & & & & & & & & \\
\hline EU & $.157^{*}$ & .929 & & & & & & & & & & & & & & & \\
\hline SE & $.028^{*}$ & $.107^{* *}$ & .956 & & & & & & & & & & & & & & \\
\hline UC & $-.097^{*}$ & * $-.068^{*}$ & $.003^{*}$ & .930 & & & & & & & & & & & & & \\
\hline $\mathrm{PT}$ & $.056^{*}$ & $.065^{*}$ & $.052^{*}$ & $-.045^{*}$ & .927 & & & & & & & & & & & & \\
\hline ISQ & $.037^{*}$ & - $\quad * * *$ & $.051^{*}$ & $.056^{*}$ & $.087^{*}$ & .903 & & & & & & & & & & & \\
\hline CT & $.676^{* *}$ & $.437^{* * *}$ & $.249^{* *}$ & $.097^{*}$ & $.236^{* * *}$ & $.074^{*}$ & .824 & & & & & & & & & & \\
\hline REL & $.094^{*}$ & $.171^{* * *}$ & $.083^{*}$ & - & $.024^{*}$ & $.748^{* x}$ & $.165^{* *}$ & .814 & & & & & & & & & \\
\hline PRS & $-.065^{*}$ & $-.050^{*}$ & $-.048^{*}$ & $-.267^{*}$ & $-.020^{*}$ & $.316^{* x}$ & $-.029^{*}$ & -.314 & ".876 & & & & & & & & \\
\hline PRT & $-.066^{*}$ & $-.045^{*}$ & $-.061^{*}$ & $-.345^{*}$ & $-.012^{*}$ & $.015^{*}$ & $.618^{* * *}$ & $* .702$ & $.613^{*}$ & .872 & & & & & & & \\
\hline FR & $.088^{*}$ & $\begin{array}{ll}- & \\
& * * *\end{array}$ & .062 & $.367^{*}$ & $.125^{* *}$ & $.736^{* x}$ & $.154^{* *}$ & *. .084 & -.058 & $-.078^{*}$ & .924 & & & & & & \\
\hline $\mathrm{SC}$ & $.076^{*}$ & $-.043^{*}$ & $-.038^{*}$ & $.267^{* * *}$ & $-.014^{*}$ & $.315^{* x}$ & $-.021^{*}$ & $-.312^{*}$ & .084 & $.284^{* *}$ & *.076 & .842 & & & & & \\
\hline $\mathrm{PF}$ & $.056^{*}$ & $-.040^{*}$ & $-.037^{*}$ & $.255^{* * *}$ & $-.010^{*}$ & $.302^{* x}$ & $-.018^{*}$ & $-.052^{*}$ & $.234^{* *}$ & $-302^{* *}$ & $.062^{*}$ & $.028^{*}$ & .886 & & & & \\
\hline PR & $-.043^{*}$ & $-.038^{*}$ & $-.029^{*}$ & $.041^{*}$ & $-.022^{*}$ & $.408^{* *}$ & $-.039^{*}$ & $-.302^{*}$ & $-.405^{*}$ & ${ }^{*}-.617^{*}$ & $* * 052$ & .092 & $.382^{*}$ & ${ }^{k *} .866$ & & & \\
\hline IC & $-.052^{*}$ & $-.031^{*}$ & $.027^{*}$ & $.035^{*}$ & $-.710^{* * *}$ & $.602^{* x}$ & $-.018^{*}$ & $.082^{*}$ & $-.533^{*}$ & * $-.408^{*}$ & ** $.0722^{*}$ & $402^{* *}$ & $.052^{*}$ & .612 & ***.901 & & \\
\hline PC & $-.557^{*}$ & $.052^{*}$ & $.045^{*}$ & $.052^{*}$ & $-.018^{*}$ & $.021^{*}$ & $-.026^{*}$ & $.302^{*}$ & $.038^{*}$ & $-.516^{*}$ & $* * 161$ & 324 & $.077^{*}$ & .531 & $* 43$ & .94 & \\
\hline UCT & $.046^{*}$ & $.065^{*}$ & $-.037^{*}$ & - & $-.062^{*}$ & $.014^{*}$ & $-.037^{*}$ & $-.302^{*}$ & -.336 & ${ }^{*}-.403^{*}$ & **.031* & $301 *$ & $.063^{*}$ & -.712 & ** .15 & $.138^{*}$ & .837 \\
\hline
\end{tabular}

$*: \mathrm{p}<0.05 ; * *: \mathrm{p}<0.01 ; * * *: \mathrm{p}<0.001$.

Note: Values on diagonal are the square root of Average Variance Extracted (AVE) between the constructs and their measures.

However, off-diagonal values are correlations between constructs. 


\subsection{Structural model validation}

After obtaining an acceptable measurement model, we apply a structural equation modelling approach to test our hypotheses described in our research model. The structural model is a tool to detect if the proposed conceptual model was providing an acceptable fit to the empirical data. Table 5 compares between the recommended and actual values of the fit indices. With the chi-square/df ratio ( $\chi 2 /$ d.f.) of 1.74 , root-mean-squared error of approximation (RMSEA $=0.04)$, comparative fit index $(\mathrm{CFI}=0.93)$, goodness of fit index $(\mathrm{GFI}=0.91)$, adjusted goodness of fit index (AGFI=0.91), normed fit index (NFI=0.94), Bollen's incremental-fit index (IFI=0.96), comparative fit index $(\mathrm{CFI}=0.96)$ all indicating that the model have an acceptable fit to data as suggested by Kline (2016).

Table 5. Comparison of model fit indices for measurement model and structural model.

\begin{tabular}{lllll} 
& & \multicolumn{2}{c}{ Measurement model } & Structural model \\
\cline { 3 - 4 } Fit indices Criterion & Initial model & Respecified model & \\
\cline { 3 - 5 } & & & & \\
\hline$\chi^{2} / d . f$. & $<3.00$ & 1.76 & 1.67 & 1.74 \\
GFI & $>0.9$ & 0.92 & 0.91 & 0.91 \\
AGFI & $>0.9$ & 0.92 & 0.91 & 0.91 \\
NFI & $>0.9$ & 0.93 & 0.95 & 0.94 \\
IFI & $>0.9$ & 0.95 & 0.97 & 0.96 \\
CFI & $>0.9$ & 0.93 & 0.97 & 0.96 \\
RMSEA & $<0.06$ & 0.05 & 0.04 & 0.04 \\
\hline
\end{tabular}

Table 6 shows findings of the structural model analysis. The majority of the paths are significant and are in the expected direction. The path coefficients of hypotheses 1, 3, 4, 5, 6, 7a, 7b, 9a, 9b, 10a, 10b, 12, 13, 14 and 16 were significant at a level of $\mathrm{p}<0.001$, indicating support for these hypotheses. The path coefficient of hypothesis 2 and 15 was significant at a level of $\mathrm{p}<0.01$, thus indicating support for this hypothesis. However, hypotheses $8 \mathrm{a}$ and $8 \mathrm{~b}$ were rejected. According to the results, Plagiarism risk has a larger direct influence on intention to adopt crowdfunding technology $(\beta=-.577, \mathrm{p}<0.001)$ followed by Perceived risk with services $(\beta=-0.385, \mathrm{p}<0.001)$, Perceived usefulness $(\beta=0.359, \mathrm{p}<0.001)$ and Perceived risk with transaction $(\beta=-0.112, \mathrm{p}<0.001)$. Interestingly, information concerns were found to have the largest direct influence $(\beta=0.512, p<0.001)$ on plagiarism risk, followed by perceived control $(\beta=-0.131, p<0.001)$. Therefore, psychological factors have a direct influence on both perceived risk with services $(\beta=0.598, \mathrm{p}<0.001)$ and perceived risk with transaction $(\beta=0.463, \mathrm{p}<0.001)$. Thus, Financing risk have a direct influence on both perceived risk with services $(\beta=0.296, p<0.001)$ and perceived risk with transaction $(\beta=0.147, \mathrm{p}<0.001)$. In addition, usage costs have a larger direct influence on Perceived usefulness $(\beta=-0.612, p<0.001)$ followed by Ease of use $(\beta=0.445, p<0.001)$ and Speed $\&$ efficiency $(\beta=0.356, p<0.01)$. However, Reliability $(\beta=0.465, \mathrm{p}<0.001)$, followed by Confidence in technology $(\beta=0.325$, $\mathrm{p}<0.001)$ and Information and service quality $(\beta=0.251, \mathrm{p}<0.001)$, have the largest direct influence on perceived trust. In Figure 2 the validated structural model is presented. 
Table 6. Results of hypothesis testing

\begin{tabular}{llllll}
\hline No. & Hypothesized path & Estimate & S.E. & C.R. & P value \\
\hline H12 & Perceived risk with services $\rightarrow$ intention to use & -.385 & .016 & -8.618 & $.000^{* * *}$ \\
H13 & Perceived risk with transaction $\rightarrow$ intention to use & -.112 & .013 & -6.486 & $.000^{* * *}$ \\
H14 & Plagiarism risk $\rightarrow$ intention to use & -.577 & .067 & -5.534 & $.000^{* * *}$ \\
H16 & Perceived usefulness $\rightarrow$ intention to use & .359 & .046 & 15.643 & $.000^{* * *}$ \\
H15 & Perceived trust $\rightarrow$ intention to use & .282 & .018 & 7.644 & $.006^{* *}$ \\
H10a & Information concerns $\rightarrow$ Plagiarism risk & .512 & .023 & 12.188 & $.000^{* * *}$ \\
H10b & Perceived control $\rightarrow$ Plagiarism risk & -.131 & .012 & -11.432 & $.000^{* * *}$ \\
H7a & Financing risk $\rightarrow$ Perceived risk with services & .296 & .017 & 10.617 & $.000^{* * *}$ \\
H8a & Security concerns $\rightarrow$ Perceived risk with services & .186 & .014 & .045 & $.565^{\text {ns }}$ \\
H9a & Psychological factors $\rightarrow$ Perceived risk with services & .598 & .013 & 8.834 & $.000^{* * *}$ \\
H7b & Financing risk $\rightarrow$ Perceived risk with transaction & .147 & .027 & 12.163 & $.000^{* * *}$ \\
H8b & Security concerns $\rightarrow$ Perceived risk with transaction & .284 & .029 & 1.486 & $.990^{\text {ns }}$ \\
H9b & Psychological factors $\rightarrow$ Perceived risk with transaction & .463 & .013 & 18.631 & $.000^{* * *}$ \\
H1 & Ease of use $\rightarrow$ Perceived usefulness & .445 & .015 & 17.623 & $.000^{* * *}$ \\
H2 & Speed and efficiency $\rightarrow$ Perceived usefulness & .356 & .029 & 6.221 & $.004{ }^{* *}$ \\
H3 & Usage costs $\rightarrow$ Perceived usefulness & -.612 & .068 & -7.661 & $.000^{* * *}$ \\
H4 & Information and service quality $\rightarrow$ Perceived trust & .251 & .014 & 5.748 & $.000^{* * *}$ \\
H5 & Confidence in technology $\rightarrow$ Perceived trust & .325 & .012 & 6.316 & $.000^{* * *}$ \\
H6 & Reliability $\rightarrow$ Perceived trust & .468 & .019 & 8.812 & $.000^{* * *}$ \\
\hline
\end{tabular}

${ }^{*}: \mathrm{p}<0.05 ;{ }^{* *}: \mathrm{p}<0.01 ;{ }^{* * *}: \mathrm{p}<0.001 ;{ }^{\mathrm{ns}}$ : not significant.

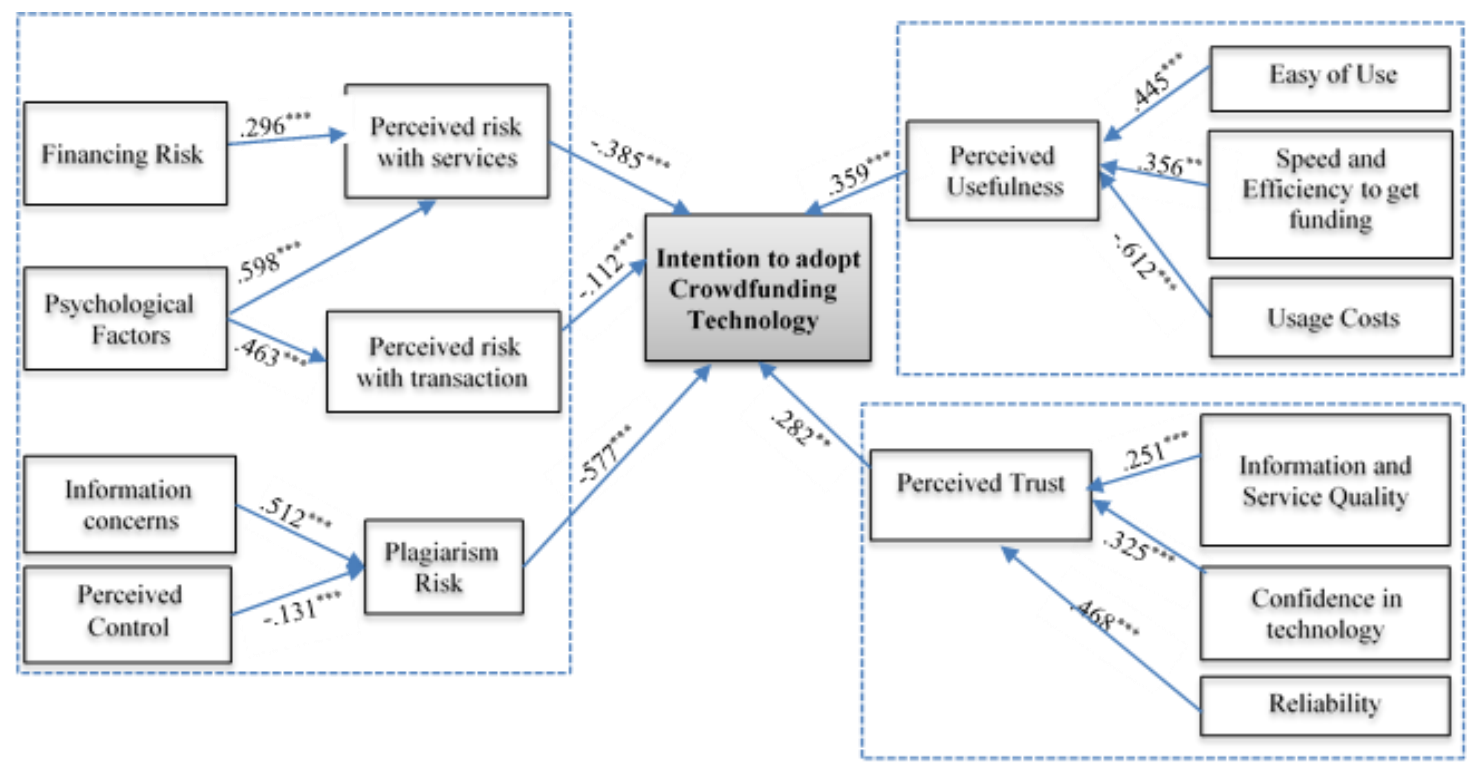

Figure 2. The validated structural model Source: authors 


\section{ENTREPRENEURSHIP AND SUSTAINABILITY ISSUES}

ISSN 2345-0282 (online) http://jssidoi.org/jesi/

2019 Volume 7 Number 1 (September)

http://doi.org/10.9770/jesi.2019.7.1(26)

\section{Discussion}

Plagiarism risk has negative effects on intention to adopt crowdfunding platforms $(\beta=-0.577, \mathrm{p}<0.001)$, showing that it is a critical determinant of acceptance to use of crowdfunding technology owing to the entrepreneur's fear of voluntary information disclosure. This result is in accordance with previous studies (Wang et al., 2018), which have argued that entrepreneurs as fundraisers are worried about the originality or the design of their project to be illegally copied by unethical users without their prior notification or agreement. Consequently, the intention to use crowdfunding platform will decrease if they recognize a high risk of plagiarism (Stutzman et al., 2011). Undeniably, the risk taken by a novice entrepreneur may influence its funding choices. As a result, various studies have evidenced risks of idea-stealing related to the often required circulation of ideas (Biais \& Perotti, 2008), such problem is qualified by Cooter \& Edlin (2013) as "double trust dilemma of innovation" (Schwienbacher, 2017).

Perceived risk with services $(\beta=-0.385, \mathrm{p}<0.001)$ and perceived risk with transaction $(\beta=-.112, \mathrm{p}<0.001)$ was found to have a negative effect on voluntary use of crowdfunding platforms by Tunisian entrepreneurs. Furthermore, psychological factors have a direct influence on both perceived risk with services $(\beta=0.598$, $\mathrm{p}<0.001)$ and perceived risk with transaction $(\beta=0.463, \mathrm{p}<0.001)$. This result means that entrepreneurs' cognition of risk and their intention to use crowdfunding services are influenced by their psychological schemes. This finding is in line with the results obtained by Hollenbaugh \& Ferris (2014), who found that online users adopt technology services to disclose their information based on extrinsic motivations. In the same way, entrepreneurs (fundraisers) believe to run an unsuccessful crowdfunding campaign once they share online information about their entrepreneurial project. Thus, they know for a fact that if they do not share details about their projects to fascinate potential funders, they cannot be entirely funded. Consequently, voluntary adoption of crowdfunding platforms depends on both risk perception with services and transaction upon crowdfunding platforms in such a way a higher risk perception with services discourage willingness to use this technology and to disclose project details voluntarily.

Information concerns were found associated positively with plagiarism risk $(\beta=0.512, p<0.001)$, showing that it plays an important role in the intention to use of crowdfunding technology. This result is consistent with the study of Bulgurcu et al. (2010) indicating a relation between information concern which, is considered as a personal disposition and privacy risk. This result indicates that if information concerns are high, entrepreneurs will be interested to protect their entrepreneurial project from plagiarism and therefore will be less willing to use crowdfunding platform.

Perceived control was found to have a negative influence on plagiarism risk $(\beta=-0.131, \mathrm{p}<0.001)$. This finding is in accordance with prior studies in the social networking service (SNS) testing the link between perceived control and information revelation (Zlatolas et al., 2015). Risk concerns about the revelation of sensitive project details can be reduced by different uses of information control. This result shows that when entrepreneurs have control on the use of their entrepreneurial project information, they become less worried about the stealing risks of their project proposals.

Financing risk was found associated positively with both perceived risk with services $(\beta=0.296, p<0.001)$ and perceived risk with transaction $(\beta=0.147, \mathrm{p}<0.001)$. This result is consistent with the study conducted by Nanda $\&$ Rhodes-Kropf, (2016) indicating that financing risk encompasses the possible failure to find future funding for novice entrepreneurs. When entrepreneurs launch a crowdfunding campaign, they may also fear financing risk. Thus, entrepreneurs could be unable to attain their financing objective owing to the revelation of irrelevant information related to their entrepreneurial project (Nanda and Rhodes-Kropf, 2016). In fact, if entrepreneurs as fundraisers did not arouse the interest of crowdfunders as investors, they may ask themselves if they have 


\section{ENTREPRENEURSHIP AND SUSTAINABILITY ISSUES}

ISSN 2345-0282 (online) http://jssidoi.org/jesi/ 2019 Volume 7 Number 1 (September) http://doi.org/10.9770/jesi.2019.7.1(26)

disclosed enough relevant information (Li et al., 2016). As a result, to satisfy crowdfunders' expectations and fascinate them, entrepreneurs may divulge more information about their entrepreneurial projects. Consequently, a high perceived risk with crowdfunding services and transaction usually results in more financing risk perception. Usage costs was found related negatively to Perceived usefulness $(\beta=-0.612, p<0.001)$. This funding is in line with previous studies indicating that usage costs have acted as an obstacle to technology acceptance (Park \& Kim, 2016; Yu, 2012). Many researches argued that usage costs and technology adoption are associated negatively according to adoption risks model (e.g., Zhou, 2011; Venkatesh et al., 2012). Some platforms claim a significant percentage (more than 10\%) of raised funds as commission for their services. While the crowdfunding service is perceived to be useful by entrepreneurs, usage costs will influence the usage intention as an adoption obstacle.

Perceived easy to use has a positive relationship $(\beta=0.445, \mathrm{p}<0.001)$ and direct effect with perceived usefulness of entrepreneurs to use crowdfunding technology. In addition, Perceived usefulness has an immediate effect on the intention to use crowdfunding platforms $(\beta=0.359, \mathrm{p}<0.001)$. This finding is consistent with the studies conducted by Bin Mohd \&Thaker (2018) and Bin Mohd et al., (2018) showing both perceived usefulness and perceived ease of use are directly significant in influencing the crowdfunder's intention to adopt the crowdfunding-waqf model (CWM) in Malaysia. In the same way, speed and efficiency was found associated positively with perceived usefulness $(\beta=0.356, \mathrm{p}<0.01)$. This result is in line with the study of Taherdoost $(2018)$ indicating that speed affect positively the acceptance of e-service technology.

Reliability was found have the largest positive affect on perceived trust $(\beta=0.465, p<0.001)$, followed by Confidence in technology $(\beta=0.325, \mathrm{p}<0.001)$ and Information and service quality $(\beta=0.251, \mathrm{p}<0.001)$. These findings are consistent with recent studies (Esraa et al., 2018; Wangari \& Karugu, 2018) indicating that customers trust online services' platforms because their confidence in technology, reliability and the quality of the provided information and service. Wang et al., (2018) talk about the increasing of trust if there is ready access to information and services. The information and service quality should facilitate the ease of use of crowdfunding service applications.

The relationship between Security concerns and Perceived risk with services was not verified $(\beta=0.186, p=0.565)$. In addition, the relationship between Security concerns and Perceived risk with transaction was not confirmed $(\beta=0.284, p=0.990)$. This result is not consistent with that of the study conducted by Nikkhah et al. (2018). One plausible explanation is that crowdfunding in Tunisia is still at an embryonic stage of development; thus, fundraisers may place much security concerns than entrepreneurs in using crowdfunding platform as they are the true fund purveyors. Moreover, entrepreneurs have no fear about the security of transferring fund from the fundraiser account to the platform.

\section{Conclusions and implications}

\section{Theoretical implications}

This study makes many contributions to the literature on crowdfunding technology adoption among novice entrepreneurs. First, while technology adoption is a very interesting research issue and has been widely studied, the topic has not been thoroughly investigated in the context of crowdfunding. However, existing literature on the use of crowdfunding platforms focus essentially on voluntary information disclosure by entrepreneurs (Li et al., 2016), thus neglecting the importance of crowdfunding technology adoption in the context of developing country where this funding tool is underdeveloped. Our current research fills this knowledge gap. This contribution aimed at investigating the factors affecting entrepreneurs' behavior intention to use crowdfunding platforms from a perspective of three distinct perception: use, trust and risk. To the best of our knowledge, this empirical study is among the first researches to scrutinize the determinants of entrepreneurs' behavior intention of voluntary use of crowdfunding platforms in developed country. 


\section{ENTREPRENEURSHIP AND SUSTAINABILITY ISSUES}

ISSN 2345-0282 (online) http://jssidoi.org/jesi/ 2019 Volume 7 Number 1 (September) http://doi.org/10.9770/jesi.2019.7.1(26)

Second, prior studies on technology adoption have often focused only on the classic TAM model as their theoretical foundation. However, risk perception with service, transaction and plagiarism was neglected. Entrepreneurs are reticent about using crowdfunding platforms to disclose information related to their entrepreneurial project because of different types of perceived risks. Consequently, perceived risk appears as a conspicuous obstacle to entrepreneurs' information disclosure behavior (Wang at al., 2015; Li et al., 2016; Wang et al., 2018). Thus, this research provides some of the first evidence for the basic validity of the classic TAM model. The findings show that perceived risks affect crowdfunding adoption among novice entrepreneurs and specially their information disclosure behavior. The application of a modified TAM model to a study of crowdfunding adoption expands the understanding of risk perception in explaining entrepreneurs' behavior.

Third, the current study provided evidence to clarify the three dimensions of risk perceptions in the context of crowdfunding especially. We divided perceived risk into perceived risk with services, perceived risk with transaction and plagiarism risk, which are supposed to form the essential of risk perceptions when an entrepreneur uses crowdfunding platform and discloses information about his entrepreneurial project. However, most of the carried studies regarding TAM model have considered perceived risk with other factors as an integral variable to explore user's behavior intention. TAM model was extended in this research by exploring different risks on entrepreneurs' intention to use crowdfunding platforms and their information disclosure behavior. Furthermore, we revealed the interesting role of plagiarism risk in predicting entrepreneurs' intention to adopt crowdfunding technology.

\section{Practical implications}

From a practical level, findings of this study can serve as a guide to entrepreneurship educators and counsellors on how to understand entrepreneurs' behaviour intention to use crowdfunding platforms. In addition, results will support crowdfunding services providers to determine the significant variables encouraging entrepreneurs' voluntary intention to adopt crowdfunding technology and to disclose information when running a crowdfunding campaign. Crowdfunding service providers have to be conscious that developing the appropriate strategies depends on both individual and contextual factors of their environment. Our findings indicate that entrepreneurs should expect differences in risk perceptions depending on their personality traits and their psychological factors. Explicitly, plagiarism risk and financing risk affect significantly entrepreneurs' intention to use crowdfunding platforms and to disclose voluntarily information of their entrepreneurial project. Consequently, crowdfunding services providers have to be aware of these risks to enhance entrepreneurs' behaviour to adopt this technology. Entrepreneurs may be vexed by disclosing their entrepreneurial project information. Thus, they require more guarantees for confidentiality of their project information. As a result, crowdfunding platforms should be customised to provide such guarantees to entrepreneurs when posting their project information on crowdfunding platforms. Perceived control is an additional interesting topic that have to be addressed. A perceived level of control over shared information increases the ability and the confidence of entrepreneurs as fundraisers to manage it and then reduces their perceptions of plagiarism risk. Crowdfunding services providers have to assure confidentiality on their platforms to encourage entrepreneurs divulging their project information according to their intention. The perceived control of entrepreneurs over their project information will increase, if they can choose which information is observable and share or retract freely their project's information.

In addition, innovative entrepreneurs can construct a competitive advantage and differentiate themselves from competitors. Nevertheless, innovative projects involved higher levels of plagiarism risk. Deterring imitation using legal barriers such as patent, copyrights, trademarks are a very interesting concern for both entrepreneurs and Crowdfunding service providers when uploading project's information on the crowdfunding platform. Therefore, to resolve these problems, crowdfunding service providers can remind entrepreneurs of their delicate information and assist them to patent their product. For the meantime, crowdfunding service providers have to tighten procedures of project evaluation and strengthen its operations management. 


\section{ENTREPRENEURSHIP AND SUSTAINABILITY ISSUES}

ISSN 2345-0282 (online) http://jssidoi.org/jesi/ 2019 Volume 7 Number 1 (September) http://doi.org/10.9770/jesi.2019.7.1(26)

Considering the significant impact of perceived usefulness and perceived trust on entrepreneurs' intention bahavior, crowdfunding service providers should express and publish procedures, policies and security measures of their platforms utilization to standardize entrepreneurs' information revelation behavior. Crowdfunding service providers should enforce online security tools and include exhaustive reports on their platforms to protect rights of their users. They can explain which information will be revealed and which is optional. As a result, crowdfunding service providers must increase the perceived usefulness and enhance the perceived trust.

\section{Limitations and suggestions for future research}

TAM model is used to detect human resistance for adopting new technologies and its robustness was confirmed by several studies. It explains and predicts IT acceptance and facilitate design changes before users have experience with a system (Dongwon Lee et al. 2001. P: 110). However, the findings of this study have some limitations that will provide opportunities for further research. First, our empirical study is restricted to a Tunisian entrepreneurs' sample. It is wiser to test whether the findings are valid in other developing countries. Thus, we should take into account both cultural, social and technological differences between countries. A very important extension of this research would be to compare entrepreneurs' intention to use crowdfunding platforms and their willingness to disclose project's information in different developing countries to scrutinize whether the important factors differ. Another future extension of this study would be to expand the data set to cover not only nascent entrepreneurs hosted in business incubator.

Second, other factors could influencing entrepreneurs' intention to use crowdfunding platforms that are not considered in the presented model. Future study can include to our model factors related to personal traits and demographic characteristics of entrepreneurs, which have been confirmed as effecting information disclosure on online services. Thus, further research may extend the TAM model by considering additional factors.

Third, the questionnaire data were collected from 208 entrepreneurs at a single point in time. A longitudinal study would more credibly investigate how entrepreneurs' intention to adopt crowdfunding technology changes over time.

\section{References}

Adams, D.A., Nelson, R.R., and Todd, P.A. (1992). Perceived Usefulness, Ease of Use, and Usage of Information Technology: A Replication. MIS Quarterly 16(2), 227-247.

Ahlers, G.K., Cumming, D., Günther, C. and Schweizer, D. (2015). Signaling in equity crowdfunding. SSRN Electronic Journal, 39(4), 955-980. https://doi.org/10.1111/etap.12157

Ajzen, I., Fishbein, M. (1977). Attitude-Behavior Relations: A Theoretical Analysis and Review of Empirical Research. Psychological bulletin, 84(5), 889-918.

Astrauskaitè, I., Paškevičius, A. (2018). An analysis of crowdfunded projects: KPI's to success. Entrepreneurship and Sustainability Issues, 6(1), 23-34. http://doi.org/10.9770/jesi.2018.6.1(2)

Bauer, R.A. (1960). Consumer behavior as risk taking, Proceedings of the $43^{\text {rd }}$ National Conference of the American Marketing Association, pp. 389-398.

Belleflamme, P. Lambert, T., Schwienbacher, A. (2011). Crowdfunding: Tapping the Right Crowd, in International Conference of the French Finance Association (AFFI), May 11-13 http://dx.doi.org/10.2139/ssrn.1578175

Belleflamme, P., Lambert, T., Schwienbacher, A. (2013). Individual crowdfunding practices. Venture Capital, 15(4), 313-333.

Biais, B., Perotti, E. (2008). Entrepreneurs and New Ideas. The RAND Journal of Economics, 39(4), 1105-1125 


\section{ENTREPRENEURSHIP AND SUSTAINABILITY ISSUES}

ISSN 2345-0282 (online) http://jssidoi.org/jesi/ 2019 Volume 7 Number 1 (September) http://doi.org/10.9770/jesi.2019.7.1(26)

Bin Mohd, M-A., Thaker, T., Pitchay, A-A. (2018). Modeling crowdfunders' behavioral intention to adopt the crowdfunding-waqf model (CWM) in Malaysia: The theory of the technology acceptance model. International Journal of Islamic and Middle Eastern Finance and Management https://doi.org/10.1108/IMEFM-06-2017-0157

Bin Mohd, M-A., Thaker, T. (2018). Factors influencing the adoption of the crowdfunding-waqf model (CWM) in the waqf land development, Journal of Islamic Marketing, 9(3), 578-597. https://doi.org/10.1108/JIMA-05-2016-0043

Bretschneider, U., Knaub, K. and Wieck, E. (2014). Motivations for crowdfunding: What drives the crowd to invest in start-ups? Twenty Second European Conference on Information Systems https://www.jstor.org/stable/25474413

Brown, T.A. (2015). Confirmatory Factor Analysis for Applied Research, 2nd edition, New York: The Guilford Press, 234 p.

Bulgurcu, B., Cavusoglu, H. and Benbasat, I. (2010). Understanding emergence and outcomes of information privacy concerns: A case of Facebook, International Conference on Information Systems, St Louis.

Cambridge Centre for Alternative Finance/KPMG (2016). Sustaining Momentum: The $2^{\text {nd }}$ European Alternative Finance Industry Report, available at: https://assets.kpmg.com/content/dam/kpmg/xx/pdf/2016/09/sustaining-momentum.pdf

Compeau, D-R, \& Higgins, C-A. (1995). Computer Self-Efficacy: Development of a Measure and Initial Test. MIS Quarterly, 19(2), 189211.

Chirisa, I., Mukarwi, L. (2018). A Comparative Analysis of Africa and Chinese Crowdfunding Markets, In, Benna, U-G. \& Benna, A-U, Crowdfunding and Sustainable Urban Development in Emerging Economies, IGI Global.

Craciun, G. (2018). Choice Defaults and Social Consensus Effects on Online Information Sharing: The Moderating Role of Regulatory Focus. Computers in Human Behavior https://doi.org/10.1016/j.chb.2018.06.019

Davis, F-D. (1989). Perceived Usefulness, Perceived Ease of Use, and User Acceptance of Information Technology. MIS Quarterly, 13(3), 319-340.

Davis, F.D., Bagozzi, R.P., Warshaw, P-R. (1989). User Acceptance of Computer Technology: A Comparison of Two Theoretical Models. Management Science, 35(8), 982-1003.

Davis, F.D., Richard, P. Bagozzi, P.R. Warshaw. (1992). Extrinsic and Intrinsic Motivation to Use Computers in the Workplace, 22(14), 1111-1132 https://doi.org/10.1111/j.1559-1816.1992.tb00945.x

Dinev, T., Bellotto, M., Hart, P., Russo, V. et al. (2006). Internet users' privacy concerns and beliefs about government surveillance: An exploratory study of differences between Italy and the United States. Journal of Global Information Management, 14(4), 57-93.

Esraa, A. Yufei, Y., Milena, H. (2018). Understanding Trust in Online Reviews - Research in Progress. SIGHCI 2018 Proceedings. https://aisel.aisnet.org/sighci2018/24

Featherman, M. and Pavlou, P. (2003). Predicting e-services adoption: A perceived risk facets perspective. International Journal of Human-Computer Studies, 59(4), 451-474. https://doi.org/10.1016/S1071-5819(03)00111-3

Fornell, C. and Larcker, D.F. (1981). Evaluating structural equation models with unobservable variables and measurement error. Journal of Marketing Research, 18(4), 39-50.

Gierczak, M. M., Bretschneider, U. \& Leimeister, J. M. (2014). Is all that Glitters Gold? Exploring The Effects of Perceived Risk on Backing Behavior in Reward-based Crowdfunding. In: International Conference on Information Systems (ICIS), Auckland, New Zealand. Hair, J.F., Anderson, R.E., Tatham, R.L. and Black, W.C. (1998). Multivariate Data Analysis, 5th edition. New Jersey: Prentice-Hall, p.367.

Hair, J.F., Black, B., Babin, B., Anderson, R.E. and Tatham, R.L. (2006). Multivariate Data Analysis, 6th ed., Prentice Hall, Upper Saddle River, NJ., p. 267.

Hollenbaugh, E. E. and Ferris, A. L. (2014). Facebook self-disclosure examining the role of traits, social cohesion and motives. Computers in Human Behavior, 30(1), 50 -58. http://dx.doi.org/10.1016/j.chb.2013.07.055 


\section{ENTREPRENEURSHIP AND SUSTAINABILITY ISSUES}

ISSN 2345-0282 (online) http://jssidoi.org/jesi/ 2019 Volume 7 Number 1 (September) http://doi.org/10.9770/jesi.2019.7.1(26)
Howe, J. (2006).
The
Rise
of
Crowdsourcing.
Wired,
14. http://www.wired.com/wired/archive/14.06/crowds.html

Kaplan, L.B., Szybillo, G.J. and Jacoby, J. (1974). Components of perceived risk in product purchase: A cross-validation. Journal of Applied Psychology, 59(3), 287-291. http://dx.doi.org/10.1037/h0036657

Kim, M-J., Chung, N., Lee, C-K. (2011). The effect of perceived trust on electronic commerce: Shopping online for tourism products and services in South Korea. Tourism Management, 32, 256-265. http://dx.doi.org/10.1016/j.tourman.2010.01.011

Kleemann, F., Vob, G., Rieder, K. (2008). Under paid Innovators: The Commercial Utilization of Consumer Work through Crowdsourcing. Science Technology and Innovation Studies, 4, 5-26.

Kline, R.B. (2016). Principles and Practice of Structural Equation Modeling, 4th edition, New York: The Guilford Press, p. 326.

Krasnova, H., Spiekermann, S., Koroleva, K. (2010). Online social networks: Why we disclose. Journal of Information Technology, 25(2), 109-125. https://doi.org/10.1057/jit.2010.6

Kromidha, E. and Robson, P. (2016). Social identity and signalling success factors in online crowdfunding. Entrepreneurship \& Regional Development, 1-25. https://doi.org/10.1080/08985626.2016.1198425

Li, D., Browne, G.J. and Chau, P.Y.K. (2006). An empirical investigation of web site use using a commitment-based model, Decision Sciences, 37(3), 427-444. https://doi.org/10.1111/j.1540-5414.2006.00133.x

Li, X.C., Tang, Y.H., Yang, N.R., Ren, R.Y. et al. (2016). The value of information disclosure and lead investor in equity-based crowdfunding: An exploratory empirical study, Nankai Business Review International, 7(3), 1-25. https://doi.org/10.1108/NBRI-01$\underline{2016-0002}$

Lee, D., Park, J., Ahn, J. (2001), On the Explanation of Factors Affecting E-Commerce Adoption, Proceedings of the 22nd International Conference on Information Systems, New Orleans, Louisiana, pp. 109-120.

Malhotra, N-K., Kim, S-S., Agarwal, J. (2004). Internet Users' Information Privacy Concerns (IUIPC): The Construct, the Scale, and a Causal Model. Information Systems Research, 15(4), 336-355. https://doi.org/10.1287/isre.1040.0032

Mollick, E. (2014). The dynamics of crowdfunding: an exploratory study. Journal of Business Venturing, 29(1), 1-16. https://doi.org/10.1016/j.jbusvent.2013.06.005

Moore, G.C., Benbasat, I. (1991). Development of an Instrument to Measure the Perceptions of Adopting an Information Technology Innovation. Information Systems Research, 2(3), 192-222. https://doi.org/10.1287/isre.2.3.192

Nanda, R. and Rhodes-Kropf, M. (2016). Financing risk and innovation. Management Science, 63(4), 901-918. https://doi.org/10.1287/mnsc.2015.2350

Nikkhah, H-R., Grover, V., Sabherwal, R. (2018), Why Do Users Continue to Use Mobile Cloud Computing Applications? A SecurityPrivacy. Proceedings of the 13th Pre-ICIS Workshop on Information Security and Privacy, San Francisco, December 13, 2018

Park, J-H., Kim, M-K. (2016), Factors influencing the low usage of smart TV services by the terminal buyers in Korea. Telematics and Informatics, 33(4), 1130-1140. http://dx.doi.org/10.1016/j.tele.2016.01.001

Park, J., Lee, D., Ahn, J. (2004). Risk-Focused E-Commerce Adoption Model: A Cross-Country Study. Journal of Global Information Technology Management, 7(2), 6-30. http://dx.doi.org/10.1080/1097198X.2004.10856370

Pazowski, P., \& Czudec, W. (2014). Economic prospective and conditions of crowdfunding 1082-1083. Retrieved from http://www.toknowpress.net/ISBN/978-961-6914-09-3/papers/ML14-685.pdf

Roca, J-C., Gagne, M. (2008). Understanding e-learning continuance intention in the workplace: A self-determination theory perspective. Computers in Human Behavior, 24, 1585-1604. https://doi.org/10.1016/j.chb.2007.06.001

Schwienbacher, A. (2017). Entrepreneurial risk-taking in crowdfunding campaigns. Small Business Economics, 51(4), 843-859. https://doi.org/10.1007/s11187-017-9965-4 


\section{ENTREPRENEURSHIP AND SUSTAINABILITY ISSUES}

ISSN 2345-0282 (online) http://jssidoi.org/jesi/ 2019 Volume 7 Number 1 (September) http://doi.org/10.9770/jesi.2019.7.1(26)

Stutzman, F., Capra, R. and Thompson, J. (2011). Factors mediating disclosure in social network sites. Computers in Human Behavior, 27(1), 590-598. https://doi.org/10.1016/j.chb.2010.10.017

Swaminathan, V., Lepkowska-White, E., and Rao, B.P. (1999). Browsers or Buyers in Cyberspace? An Investigation of Factors Influencing Electronic Exchange, Journal of Computer Mediated Communication 5(2). https://doi.org/10.1111/j.1083-6101.1999.tb00335.x

Wang, S., Han, L., Gao, W. (2015). Mandatory and voluntary information disclosure and the effects on financial analysts: Evidence from China. Chinese Management Studies, 9(3), 425-440. https://doi.org/10.1108/CMS-01-2015-0012

Wang, T., Liu, X., Kang, M., Zheng, H. (2018). Exploring the Determinants of Fundraisers' Voluntary Information Disclosure on Crowdfunding Platforms: A Risk-perception Perspective, Online Information Review, 42(3), 324-342, https://doi.org/10.1108/OIR-11$\underline{2016-0329}$

Wangari, M. J. \& Karugu, J. (2018). Micro contextual characteristics and implementation of online banking system in Family Bank Limited. International Academic Journal of Human Resource and Business Administration, 3(4), 291-314

World Bank. (2015). Crowdfunding in Emerging Markets: Lessons from East African Startups, The World Bank Group 1818 H Street NW Washington, DC 20433.

Rose, G., Khoo, H., and Straub, D.W. (1999). Current Technological Impediments to Business-to Consumer Electronic Commerce. Communications of the AIS, 1(16), 1-74.

Shin, D., Hwang, Y. (2017). Integrated acceptance and sustainability evaluation of Internet of Medical Things: A dual-level analysis. Internet Research, 27(5), 1227-1254, https://doi.org/10.1108/IntR-07-2016-0200

Shin, D-H., Biocca, F. (2017). Explicating user behavior toward multi-screen adoption and diffusion: User experience in the multi-screen media ecology. Internet Research, 27(2), 338-361, https://doi.org/10.1108/IntR-12-2015-0334

Suh, B, Han I. (2003). The Impact of Customer Trust and Perception of Security Control on the Acceptance of Electronic Commerce. International Journal of Electronic Commerce 7(3), 135-161 https://doi.org/10.1080/10864415.2003.11044270

Taherdoost, H. (2018). Development of an adoption model to assess user acceptance of e-service technology: E-Service Technology Acceptance Model, Behaviour \& Information Technology. 37(2): 173-197https://doi.org/10.1080/0144929X.2018.1427793

Taherdoost, H. (2017). Understanding of E-Service Security Dimensions and its Effect on Quality and Intention to Use. Information and Computer Security, 25(5), 535-559. https://doi.org/10.1108/ICS-09-2016-0074

Taherdoost, H., Sahibuddin, S. (2015), A Review Paper on E-Service; Technology Concepts. Procedia Technology, 19: 1067-1074. https://doi.org/10.1016/i.protcy.2015.02.152

Taylor, S., Todd, P-A. (1995). Understanding Information Technology Usage: A Test of Competing Models. Information Systems Research, 6(2), 144-176. https://doi.org/10.1287/isre.6.2.144

Terry, H-P., Schwartz, D., Sun, T. (2015). The future of finance: the socialization of Finance, Equity Research, Goldman Sach \& Co, 62 p. file:///C:/Users/Manuela/Downloads/TheFutureofFinance_Part_3_03-13-15.pdf

Venkatesh, V., Morris, M-C., Davis, G-B., Davis, F-D. (2003). User Acceptance of Information Technology: Toward a Unified View. MIS Quarterly, 27(3), 425-478. https://doi.org/10.2307/30036540

Venkatesh, V., Thong, J.Y., Xu, X. (2012). Consumer acceptance and use of information technology: Extending the unified theory of acceptance and use of technology. MIS Quarterly, 36(1), 157-178. https://ssrn.com/abstract=2002388

Venkatesh, V., and Davis, F.D. (2000). A Theoretical Extension of the Technology Acceptance Model: Four Longitudinal Field Studies. Management Science, 46(2), 186-204. https://doi.org/10.1287/mnsc.46.2.186.11926

Venkatesh, V. (1999). Creation of Favorable User Perceptions: Exploring the Role of Intrinsic Motivation. MIS Quarterly, 23(2), 239-260. https://doi.org/10.2307/249753

Venkatesh, V., Bala, H. (2008). Technology Acceptance Model 3 and a Research Agenda on Interventions. Decision Sciences, 39(2), 273315. https://doi.org/10.1111/j.1540-5915.2008.00192.x 


\section{ENTREPRENEURSHIP AND SUSTAINABILITY ISSUES}

ISSN 2345-0282 (online) http://jssidoi.org/jesi/ 2019 Volume 7 Number 1 (September)

http://doi.org/10.9770/jesi.2019.7.1(26)

Wu, Y-L., Tao, Y-H., Yang, P-C. (2008) The use of unified theory of acceptance and use of technology to confer the behavioral model of 3G mobile telecommunication users. Journal of Statistics \& Management Systems, 11(5), 919-949. https://doi.org/10.1080/09720510.2008.10701351

$\mathrm{Xu}, \mathrm{F}$., Michael, K. and Chen, X. (2013). Factors affecting privacy disclosure on social network sites an integrated model. Electronic Commerce Research, 13(2), 151-168. https://doi.org/10.1007/s10660-013-9111-6

Xu, H., Dinev, T., Smith, H.J. and Hart, P. (2008). "Examining the formation of individual's privacy concerns: toward an integrative view", Proceedings of the 29th International Conference on Information Systems, pp.1-16.

Yu, C.S. (2012). Factors affecting individuals to adopt mobile banking: Empirical evidence from the UTAUT model. Journal of Electronic Commerce Research, 13(2), 104-121.

Zheng, H., Hung, J-L., Qi, Z., Xu, B. (2016). The role of trust management in reward-based crowdfunding, Online Information Review, 40(1), 97-118, https://doi.org/10.1108/OIR-04-2015-0099

Zhou, T. (2011). Examining the critical success factors of mobile website adoption. Online Information Review, 35(4), 636-652.

Zlatolas, L.N., Tatjana, W., Hericko, M. and Holbl, M. (2015). Privacy antecedents for SNS self-disclosure: The case of Facebook. Computers in Human Behavior, 45(1), 158-167. https://doi.org/10.1108/14684521111161972

Raouf JAZIRI holds a PhD in Management from the University of Brest (France). Actually he is Assistant Professor in College of Business at the University of Jeddah (KSA). He received a B.A. in Sciences and Mathematics, a Bachelor degree in Accounting Management, and holds three master's degrees in Entrepreneurship, International Trade and Universities' Management. He has held several positions staff such as: chief of accounting service at the University of the Center (Tunisia), Director of the sectorial Center of administration's vocational training of Sousse (Tunisia). Broadly, Dr. Raouf methodological research focuses on entrepreneurship, corporate entrepreneurship, social entrepreneurship, academic entrepreneurship, sustainable tourism, Higher education quality management and Open Educational Resources.

ORCID ID: $\underline{\text { https://orcid.org/0000-0001-5891-7282 }}$

Mohammad MIRALAM, PhD (USA) is actually an Associate Professor and Head Department of Business Administration of the College of Business at the University of Jeddah. He published widely journal articles and regularly presents his research in international academic conferences in Management. in College of Business at the University of Jeddah (KSA).

ORCID ID: $\underline{\text { https://orcid.org/0000-0002-2809-8906 }}$

Copyright (C) 2019 by author(s) and VsI Entrepreneurship and Sustainability Center This work is licensed under the Creative Commons Attribution International License (CC BY). http://creativecommons.org/licenses/by/4.0/ 